\title{
Designing the ASPIRE-SSI study: a multicenter, observational, prospective cohort study to assess the incidence and risk factors of surgical site and bloodstream infections caused by Staphylococcus aureus in Europe
}

Authors:

Darren P.R. Troeman ${ }^{1,2}$, Susanne Weber ${ }^{3,4}$, Derek Hazard ${ }^{3,4}$, Martin Wolkewitz ${ }^{3,4}$, Leen Timbermount ${ }^{5}$, Tuba Vilken ${ }^{5}$, Stephan Harbarth ${ }^{6}$, Omar Ali ${ }^{7}$, Frangiscos Sifakis ${ }^{8}$, Jan A.J.W. Kluytmans ${ }^{1,2,9}$

Author affiliations:

1. Julius Center for Health Sciences and Primary care, University Medical Center Utrecht, Utrecht, The Netherlands

2. Utrecht University, Utrecht, The Netherlands

3. Institute for Medical Biometry and Statistics, Faculty of Medicine and Medical Center, University of Freiburg, Freiburg im Breisgau, Germany

4. Freiburg Center for Data Analysis and Modeling, University of Freiburg, Freiburg im Breisgau, Germany

5. Laboratory of Medical Microbiology, Vaccine \& Infectious Disease Institute (VAXINFECTIO), University of Antwerp, Wilrijk, Belgium

6. Infection Control Programme and WHO Collaborating Center, Geneva University Hospitals and Faculty of Medicine, Geneva, Switzerland

7. Microbial Sciences, BioPharmaceuticals R\&D, AstraZeneca, Gaithersburg, Maryland, U.S.A. 
medRxiv preprint doi: https://doi.org/10.1101/2020.07.08.20148791; this version posted July 10,2020 . The copyright holder for this preprint (which was not certified by peer review) is the author/funder, who has granted medRxiv a license to display the preprint in perpetuity. It is made available under a CC-BY-ND 4.0 International license.

8. Boehringer Ingelheim Pharmaceuticals, Inc, Ridgefield, Connecticut, U.S.A.

9. Amphia Hospital, Breda, The Netherlands

\section{Corresponding author:}

Darren P.R. Troeman, Julius Center for Health Sciences and Primary care, Utrecht Medical Center

Utrecht, Postal address: Huispost nr. STR 6.131, P.O. Box 85500, 3508 GA Utrecht, The Netherlands.

Email address: D.P.R.Troeman@umcutrecht.nl

Word count: 4968 
medRxiv preprint doi: https://doi.org/10.1101/2020.07.08.20148791; this version posted July 10, 2020 . The copyright holder for this preprint (which was not certified by peer review) is the author/funder, who has granted medRxiv a license to display the preprint in perpetuity.

It is made available under a CC-BY-ND 4.0 International license .

\section{ABSTRACT}

Background: There is a continuing need for in-depth and updated knowledge about the epidemiology of surgical site infections (SSIs) caused by Staphylococcus aureus to support the development of effective preventive interventions. The ASPIRE-SSI study aims primarily to determine the incidence of $S$. aureus SSIs and postoperative bloodstream infections (BSIs) in Europe and to assess their association with patient-related, pathogen-related, and contextual risk factors.

Methods: ASPIRE-SSI is a prospective, multicenter, observational cohort study primarily assessing the incidence of and risk factors for S. aureus SSI and postoperative BSI in Europe. Five thousand adult surgical patients (of which two-thirds will be $S$. aureus carriers and one-third non-carriers) undergoing several types of surgical procedures in sites located across Europe were enrolled in the study. Data and specimens were collected from these subjects who were followed for up to 90 days following surgery to assess study outcomes.

Using advanced survival analyses and regression techniques (including competing risks models), we will determine event-specific and sub-distribution hazards to assess the independent associations of these study outcomes with risk factors. Additionally, a risk prediction model will be derived to quantify the risk of developing SSI or BSI due to S. aureus.

Discussion: Despite the challenges, this study will provide important and contemporary information about the epidemiology of SSI and BSI (and other infections) caused by S. aureus in the current surgical population in Europe, thereby supporting the development of effective preventive interventions.

Trial registration: clinicaltrial.gov number NCT02935244 
medRxiv preprint doi: https://doi.org/10.1101/2020.07.08.20148791; this version posted July 10,2020 . The copyright holder for this preprint (which was not certified by peer review) is the author/funder, who has granted medRxiv a license to display the preprint in perpetuity. It is made available under a CC-BY-ND 4.0 International license.

\section{KEYWORDS}

\section{Staphylococcus aureus}

Surgical site infection

Postoperative infection

Bloodstream infection

\section{Bacteremia}

Staphylococcus aureus carriage

Epidemiological study

\section{Europe}


medRxiv preprint doi: https://doi.org/10.1101/2020.07.08.20148791; this version posted July 10, 2020. The copyright holder for this preprint (which was not certified by peer review) is the author/funder, who has granted medRxiv a license to display the preprint in perpetuity. It is made available under a CC-BY-ND 4.0 International license.

\section{INTRODUCTION}

Surgical patients are at risk of acquiring healthcare-associated infections (HAls) (1). Studies show that up to $10 \%$ of these patients acquire at least one type of HAl during their hospital stay $(2,3)$. A substantial proportion of HAls developed among surgical patients are surgical site infections (SSIs) $(2,4)$, which are associated with considerable morbidity and mortality, and increased healthcare costs $(5,6)$. Staphylococcus aureus, which is a commensal in approximately $20-30 \%$ of the healthy human population $(7,8)$, is one of the most common and important pathogens that cause SSIs $(4,9)$. Nasal carriage of $S$. aureus has been identified as an important risk factor for $S$. aureus infection $(7,8)$.

Despite the current standard of care, availability of antimicrobial therapies, and use of infection control measures, infections caused by $S$. aureus remain a serious health condition in high-risk patient populations, including surgical patients (10). In addition, the emergence of antibiotic-resistant S. aureus strains has increased the burden of staphylococcal disease (11). Being able to accurately identify patients in an early stage who bear a disproportionate risk of $S$. aureus infection may be an important approach in improving the prevention and management of these infections $(12,13)$, as well as allowing novel interventions to target such high-risk patients (14). To effectively study and implement such therapies, a current, in-depth understanding of the epidemiology and natural history of S. aureus infections in this population is critical. Prospective studies, such as this one, will enable the assessment of risk factors by which the subsets of patients that may benefit most from these interventions can be identified.

As such, the aim of this study is to systematically assess the patient-related, pathogen-related, and contextual factors on the incidence of $S$. aureus infections, particularly $S$. aureus SSI and postoperative bloodstream infection (BSI), in the current population of surgical patients in Europe. In addition, we aim 
medRxiv preprint doi: https://doi.org/10.1101/2020.07.08.20148791; this version posted July 10,2020 . The copyright holder for this preprint (which was not certified by peer review) is the author/funder, who has granted medRxiv a license to display the preprint in perpetuity. It is made available under a CC-BY-ND 4.0 International license.

to identify the patient subgroups that bear a disproportionate high risk of developing an S. aureus infection after surgery. 
medRxiv preprint doi: https://doi.org/10.1101/2020.07.08.20148791; this version posted July 10, 2020 . The copyright holder for this preprint (which was not certified by peer review) is the author/funder, who has granted medRxiv a license to display the preprint in perpetuity.

It is made available under a CC-BY-ND 4.0 International license .

\section{METHODS}

\section{Study design}

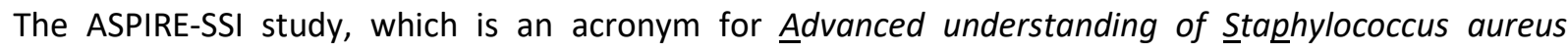
infections in Europe - Surgical Site Infections, is a prospective, observational, multicenter cohort study. It is part of the COMBACTE consortium (COMBatting AntibiotiC resisTance in Europe) (15), which aims to expedite the development of novel antimicrobial treatments and diagnostic tests in the fight against antibiotic resistance.

Two study populations can be distinguished within the ASPIRE-SSI study; a source population and a study cohort population. The study cohort population is nested within the source population, meaning that all data and study specimens that are collected for the study cohort population is in addition to the data that is collected for the source population. Sites in countries located across the four European subregions, as described by the United Nations (16), enrolled patients for this study. Patient enrollment started in December 2016 and ended in January 2020. Approvals from the Research Ethics Committees/Institutional Review Boards in the different countries/sites were obtained prior to patient enrollment at any site. A scheme of the study procedures can be found in the online supplemental material of this article (Supplemental Material: Tables 1 and 2).

\section{Study objectives}

The main aims of this study are:

- To systematically assess the incidence of S. aureus SSI (composite of superficial, deep, and organ/space S. aureus SSI) and BSI up to 90 day following surgery, and determine its 
medRxiv preprint doi: https://doi.org/10.1101/2020.07.08.20148791; this version posted July 10, 2020 . The copyright holder for this preprint (which was not certified by peer review) is the author/funder, who has granted medRxiv a license to display the preprint in perpetuity.

It is made available under a CC-BY-ND 4.0 International license.

independent association with patient-related, pathogen-related and contextual factors in the current population of surgical patients in Europe.

- To develop risk prediction models to quantify the risk of developing a S. aureus SSI (composite of superficial, deep, and organ/space S. aureus SSI) and BSI following surgery in the current population of surgical patients in Europe.

A complete list of study objectives can be found on Clinicaltrials.gov, under study identifier

NCT02935244, or in the online supplemental material of this article (Supplemental Material: Study Objectives).

\section{Eligibility criteria}

\section{Inclusion criteria}

The following inclusion criteria were met by every subject that participated in the ASPIRE-SSI study:

1. The subject was 18 years of age or older.

2. The subject underwent one of the surgical procedures ${ }^{*}$ included in the study. The surgical procedure was planned or unplanned.

3. The subject underwent $S$. aureus screening of the nose, throat and perineum within 30 days prior to surgery to assess $S$. aureus colonization, and based on the preoperative $S$. aureus colonization status of the subject, the subject qualified for enrollment in the study cohort population. Only in the case of emergency surgery when it was not possible to screen the three body regions, could subjects qualified for enrollment in the study based on S. aureus screening of at least two body regions, including the nose.

4. Written informed consent was obtained prior to enrollment in the study cohort population. 
medRxiv preprint doi: https://doi.org/10.1101/2020.07.08.20148791; this version posted July 10, 2020 . The copyright holder for this preprint (which was not certified by peer review) is the author/funder, who has granted medRxiv a license to display the preprint in perpetuity. It is made available under a CC-BY-ND 4.0 International license.

*The surgical procedures included in this study were: craniotomy, laminectomy, spinal fusion, central artery reconstructive surgery, peripheral artery bypass surgery, mastectomy, open cardiac surgery, implantable cardioverter defibrillator (ICD) implantation, emergency surgery, hip prosthesis surgery and knee prosthesis surgery. The rationale for including these procedures in this study can be found in the Discussion's section of this research paper.

\section{Exclusion criteria}

Potential subjects who met any of the following exclusion criteria were excluded from participation in the study:

1. Parallel participation in any preventative anti-Staphylococcal intervention study.

2. An active SSI diagnosis as the reason for undergoing surgery.

3. Not able to comply with study procedures and follow-up based on investigator judgment.

\section{Patient recruitment and study populations}

Adult patients (i.e. 18 of age or older) undergoing one of the surgical procedures included in the study were potentially eligible for inclusion in the study and comprised the target population of the study. The local study teams or treating specialist (or delegate), as per local regulations, approached these patients to obtain informed consent. If a patient was unable to give informed consent, an authorized surrogate of the patient was approached for consent on the patient's behalf, as per local regulations. The patients who consented were screened for S. aureus colonization in the nose, throat and perineum within 30 days prior to surgery. These subjects comprised the source population of the study. These subjects could subsequently be included in the study cohort population using an enrichment approach that was based on the preoperative S. aureus colonization status. The preoperative S. aureus screening procedure was standardized across participating sites and laboratories for consistency of screening results. We 
medRxiv preprint doi: https://doi.org/10.1101/2020.07.08.20148791; this version posted July 10, 2020 . The copyright holder for this preprint (which was not certified by peer review) is the author/funder, who has granted medRxiv a license to display the preprint in perpetuity. It is made available under a CC-BY-ND 4.0 International license .

provided each participating site with screening swabs and swabbing instructions, including instructions on how to store the swabs and transport the swabs to the local laboratories. Also, each participating laboratory received the same plating materials and processing instructions, including instructions on how to culture the samples and report the screening results. The collected screening swabs were analyzed immediately by semi-quantitative culture on chromogenic agar plates (Colorex agar, bioTRADING Benelux) at the local laboratories to determine the preoperative $S$. aureus colonization status of the subjects.

We used the following enrichment approach to enroll study subjects from the source population in the study cohort: for every two S. aureus colonized subjects we included one non-colonized subject, provided that they underwent surgery. Only subjects with evaluable results for all three preoperative screening samples could be classified as either $S$. aureus colonized (at least one result positive for $S$. aureus) or non-colonized (three negative results for S. aureus) and could therefore be enrolled in the study cohort population. An exception to this rule was made for subjects undergoing emergency surgery, as the collection of all three screening samples could be challenging in the emergency setting. For these subjects, evaluable results of at least two swabs, including the nasal swab, were needed for the determination of the preoperative $S$. aureus colonization status of the subject. For this study, we defined emergency surgery as an unplanned surgical procedure that was performed on a subject whose clinical acuity was assessed as requiring surgery within 72 hours after hospital admission.

To ensure that subjects were included in the study cohort population before they developed the first signs of postoperative infection, we instructed the local study teams to enroll subjects in the study cohort within 72 hours after the index surgery. To ensure that an evaluable number of subjects was enrolled in the study cohort for each of the protocol-defined surgical procedures, we also stratified enrolment according to surgical procedure. Once the subjects were enrolled in the study cohort 
medRxiv preprint doi: https://doi.org/10.1101/2020.07.08.20148791; this version posted July 10, 2020 . The copyright holder for this preprint (which was not certified by peer review) is the author/funder, who has granted medRxiv a license to display the preprint in perpetuity. It is made available under a CC-BY-ND 4.0 International license.

population, they were followed for 90 days following their surgery to assess study outcomes. An overview of the study procedures per study population can be found in the online supplemental material of this article (Supplemental Material: Tables 1 and 2).

\section{Study outcomes}

The primary outcome of this study evaluates the incidence of S. aureus SSI (composite of superficial, deep, and organ/space SSI) up to 90 days following surgery. The main secondary outcomes include the incidence of serious S. aureus SSI (i.e. deep and organ space SSI); S. aureus bloodstream infections (BSIs) after surgery; as well as all postsurgical S. aureus infections. S. aureus strains involved in colonization and infection will also be characterized and the role of anti-S. aureus antibodies as potential biomarkers for S. aureus infection will be explored. In addition, we will develop a prediction model to quantify the risk of acquiring a S. aureus SSI or BSI using a composite score of independent risk factors. The study definitions for the various types of infections, including SSIs, are based on the widely-used CDC definitions $(17,18)$. A complete list of study outcomes can be found on Clinicaltrials.gov, under study identifier NCT02935244, or in the online supplemental material of this article (Supplemental Material: Study outcomes).

\section{Site selection}

Sites could only be selected for this study if they had at least one corresponding microbiology laboratory that fulfilled the study requirements with respect to e.g. sample processing and storage, and that could be selected for this study. The sites were selected from lists of hospitals and corresponding microbiology laboratories that are part of the COMBACTE consortium (CLIN-Net and LAB-Net networks respectively) (15) and that meet certain quality and capability requirements. A total of 34 sites with corresponding microbiology laboratories in 10 different European countries were selected to take part in this study. 
medRxiv preprint doi: https://doi.org/10.1101/2020.07.08.20148791; this version posted July 10, 2020 . The copyright holder for this preprint (which was not certified by peer review) is the author/funder, who has granted medRxiv a license to display the preprint in perpetuity. It is made available under a CC-BY-ND 4.0 International license.

The sites and laboratories were selected by a Site Selection Committee (SSC) comprised of representatives from the University Medical Center Utrecht, the University of Antwerp, and Medlmmune/AstraZeneca. The selection process was based on pre-defined criteria described in a Site Selection Plan. These criteria were based on the capability of the hospital staff to access and recruit the target population for the study and to collect follow-up data and specimens from study participants; the experience of the hospital staff with conducting clinical studies; the capability of the local microbiology laboratory; and the anticipated timelines for regulatory approvals and contracting negotiations. The assessment of these criteria was carried out by feasibility questionnaires completed by the sites and laboratories. Only sites that fulfilled all study requirements and that were considered fully capable of taking part in the study by all voting SSC members based on the feasibility data, were selected for the study.

To ensure that the study cohort population would be representative of the European continent (even outside the European Union), a pan-European approach was undertaken when assessing and selecting participating sites for this study. Sites were selected such that factors like geography, background antibiotic resistance prevalence, and number and type of surgical procedures were adequately balanced between the four European sub-regions (16). At least two countries from the Northern, Southern, Eastern and Western European region were included. To prevent delays in enrolment and ensure study completion within expected timelines, back-up sites were selected to replace or supplement primary selected sites that could withdraw from participation or that would have lower than expected recruitment rates. 
medRxiv preprint doi: https://doi.org/10.1101/2020.07.08.20148791; this version posted July 10, 2020 . The copyright holder for this preprint (which was not certified by peer review) is the author/funder, who has granted medRxiv a license to display the preprint in perpetuity. It is made available under a CC-BY-ND 4.0 International license .

\section{Statistical methods}

\section{$\underline{\text { Sample size calculation }}$}

The sample size for the study cohort population was based on the expected incidence precision of $S$. aureus SSI. Assuming an incidence of S. aureus SSI of approximately $1.5 \%$ in the target population (19), a prevalence of S. aureus colonization in the target population of $20 \%(7)$ and an eightfold (20) increased risk of developing an S. aureus SSI for subjects colonized with S. aureus compared with non-colonized subjects, we expected an S. aureus SSI incidence of $5 \%$ for S. aureus colonized subjects and $0.6 \%$ for non-colonized subjects. Furthermore, in the calculation of the sample size we also took into account that the study population should reflect the pan-European surgical population and that all eligible types of surgical procedures for inclusion in the study would be represented in sufficient numbers (see section "eligibility criteria" for an overview of the eligible surgical procedures). Based on this, we calculated that approximately 500 subjects needed to be enrolled per surgical procedure (except for spinal fusion and laminectomy, as these two surgical procedures will together include 500 patients), of which two-thirds would be S. aureus colonized. In total, we planned to enroll approximately 5000 patients in the study cohort. With this sample size, we expected an incidence estimate of S. aureus SSI of approximately $3 \%$ within each surgical procedure, with an incidence precision of $1.5 \%$ (95\% confidence interval 1.5-4.5, using normal approximation). To achieve this sample size, we assumed that approximately 15.000 to 20.000 patients would need to be screened for assessment of preoperative $S$. aureus colonization status.

\section{$\underline{\text { Planned analysis }}$}

The primary analysis will evaluate the cumulative incidence of $S$. aureus SSI up to 90 days following surgery. Estimates of cumulative incidence of serious S. aureus SSI, S. aureus BSI, other postoperative $S$. aureus infections, and all-cause SSI will also be calculated. In a secondary analysis, the incidence density of S. aureus SSI and postoperative mortality up to 90 days following surgery will be estimated. 
medRxiv preprint doi: https://doi.org/10.1101/2020.07.08.20148791; this version posted July 10, 2020 . The copyright holder for this preprint (which was not certified by peer review) is the author/funder, who has granted medRxiv a license to display the preprint in perpetuity. It is made available under a CC-BY-ND 4.0 International license.

Competing risk methodology will be used to estimate the incidence functions (21). Death without $S$. aureus SSI will be considered a competing event for S. aureus SSI. We will apply adapted Cox regression models for event-specific and sub-distribution hazards of SSIs to determine independent associations between outcomes and risk factors. To account for clustering of data (e.g. patients undergoing the same surgical procedure, patients in the same country) and random effects by sites, shared frailty methodology, stratification or robust variance will be applied. Hazard ratios with $95 \%$ confidence intervals will be calculated univariately and selected for multivariate model using established Akaike's information criterion for model selection $(22,23)$. Missing values will be accounted for using multiple imputation (24).

The risk prediction model will be derived using a logistic regression model and candidate predictors identified through the risk factor analysis. For variable selection, a backward selection methodology will be applied. The overall model performance will be assessed by measuring the explained variation and by determining the calibration and discrimination of the model. The final model will be internally validated by bootstrapping (12). In a secondary analysis we will take the time-to-event of interest (e.g. S. aureus SSI) into account, and consider death without the event of interest as a possible competing event. In order to account for the matching procedure in the risk prediction model, we will incorporate weights into the model. Weights will be calculated using data collected from the source population. This will ensure that the population used for the derivation of the risk prediction model is representative of the target population.

\section{Quality assurance}

The participating sites collected data from the study subjects and entered this data into a webbased electronic data capture system specifically built for this study. All participating study 
medRxiv preprint doi: https://doi.org/10.1101/2020.07.08.20148791; this version posted July 10,2020 . The copyright holder for this preprint (which was not certified by peer review) is the author/funder, who has granted medRxiv a license to display the preprint in perpetuity. It is made available under a CC-BY-ND 4.0 International license.

subjects received a subject ID. The information linking this subject ID to the subject's medical information at the site was kept at a secure location at the participating site.

This study was also monitored. The monitoring by external auditors included $100 \%$ source data verification (SDV) for $10 \%$ of the total number of subjects enrolled in the study cohort at each participating site, including the SDV of the first three enrolled study cohort subjects (with a maximum of 15 study cohort subjects per participating hospital). In addition, each study cohort subject with an infection diagnosis and/or positive culture results underwent monitoring by at least one medical monitor to assure that the reported data was accurate, complete and in agreement with the study definitions for infections. 
medRxiv preprint doi: https://doi.org/10.1101/2020.07.08.20148791; this version posted July 10, 2020 . The copyright holder for this preprint (which was not certified by peer review) is the author/funder, who has granted medRxiv a license to display the preprint in perpetuity.

It is made available under a CC-BY-ND 4.0 International license .

\section{DISCUSSION}

This manuscript describes the study design and objectives of the ASPIRE-SSI study, a prospective observational study that aims to evaluate the occurrence of SSI and other postoperative infections caused by S. aureus in surgical patients in Europe and to identify subgroups of patients at high risk of these infections. During the conception of this study we made certain choices that require further discussion.

\section{$\underline{\text { Surgical procedures }}$}

The surgical procedures for this study were selected based on our current knowledge of surgical procedures that are widely performed and that are associated with a substantial burden of postoperative S. aureus infections (18). This makes them potential targets for future anti-staphylococcal preventive interventions. We assumed the following when selecting the surgical procedures for this study: (1) the main risk factor for developing an SSI is the surgical procedure itself from the time of incision to wound closure, (2) there is no $S$. aureus strain specificity for certain surgical procedures, and (3) the pathophysiology of and patient- and procedure-related risk factors for S. aureus SSI infections following these surgical procedures would be similar across similar surgeries (i.e. the results can be extrapolated to similar surgical procedures).

\section{Enrichment strategy and representativeness of study cohort population}

Nasal S. aureus colonization has already been identified as an important risk factor for developing infections with S. aureus, particularly in the surgical setting. However, studies have shown that the prevalence of $S$. aureus colonization in the community is only about 20 to $30 \%(7,8)$. For this reason, we enriched the study cohort population with $S$. aureus colonized subjects. We did this by enrolling $S$. aureus colonized and non-colonized subjects in a 1:2 ratio in the study cohort, thereby increasing the 
medRxiv preprint doi: https://doi.org/10.1101/2020.07.08.20148791; this version posted July 10, 2020 . The copyright holder for this preprint (which was not certified by peer review) is the author/funder, who has granted medRxiv a license to display the preprint in perpetuity. It is made available under a CC-BY-ND 4.0 International license.

prevalence of S. aureus colonization in the study cohort population to $67 \%$. By doing this, we expected to increase the number of $S$. aureus SSIs events, which in turn would allow for better incidence determination, risk prediction and biomarker estimations. Additionally, by including non-colonized subjects sequentially after at least two colonized subjects, we expected to be able to assess differences between S. aureus colonized and non-colonized subjects and ensure a similar temporal distribution of enrolled S. aureus colonized and non-colonized subjects. We are convinced that this will increase the robustness of the study results.

Because only a selection of screened subjects was enrolled in the study cohort, one could argue whether the study cohort population was representative of the larger surgical population. This is especially important when the data collected is used for risk prediction. We tried our best to ensure that the study cohort population would be a good representation of the target population through our study design. However, to be able to explore this further, we collected completely anonymized baseline data on certain factors (e.g. age and sex) from the entire target population. This data will be used to compare the distribution of these factors between the study cohort and the broader target population. By doing this, we will be able to assess the external validity of the study cohort population and ascertain potential selection bias between study participants and non-participants. In addition, we will use the target population data to derive weights that will be incorporated in the risk prediction models as a way to account for the matching procedure.

\section{Preoperative S. aureus colonization}

Subjects from the source population were enrolled in the study cohort based on their preoperative colonization status. However, the determination of preoperative colonization status was based only on a one-time measurement of swabs taken from the nose, throat and perineum. Studies have shown that approximately $20 \%$ of the healthy human population is persistent S. aureus carrier, $30 \%$ is intermittent 
medRxiv preprint doi: https://doi.org/10.1101/2020.07.08.20148791; this version posted July 10, 2020 . The copyright holder for this preprint (which was not certified by peer review) is the author/funder, who has granted medRxiv a license to display the preprint in perpetuity. It is made available under a CC-BY-ND 4.0 International license .

S. aureus carrier, and $50 \%$ is persistent non-carrier of $S$. aureus in the nose (7). Thus, it is highly probable that the S. aureus colonized patients identified in this study were a mixture of persistent and intermittent carriers, whereas the non-carriers of $S$. aureus were a mixture of persistent non-carriers and intermittent carriers.

Persistent carriers are known to carry higher loads of S. aureus and to shed bacteria more heavily than intermittent carriers $(25,26)$. On the contrary, carriers with lower loads of $S$. aureus may not be easily identified as carriers of $S$. aureus when screening swabs are directly plated onto culture media without prior cultivation in growth media (as is done in this study). Because of this, patients with lower loads of S. aureus may wrongly be classified as non-carriers, which could lead to misclassification. While this could be the case, the method used in this study to screen patients matched normal clinical practice, which makes the results more generalizable. Also, patients with very low loads of $S$. aureus colonization (i.e. colonization is only evident after enriching the culture sample prior to plating) are probably not at a higher risk of infection with S. aureus (26). Consequently, we did not anticipate that this would lead to a noteworthy bias. However, by doing semi-quantitative culture of the screening swabs (as is done in this study), we will get an estimation of the bacterial load of $S$. aureus colonization of each enrolled S. aureus carrier. This will hopefully allow us to assess whether our assumptions are corroborated by the study data.

Additionally, patients could be colonized with S. aureus at several body regions or extra-nasally only, and screening patients by swabbing only the nose could wrongly identify a patient as being non-carrier. By swabbing three body regions for $S$. aureus colonization, we have increased our chances of identifying all S. aureus carriers.

Another potential source of misclassification could be that in some countries and sites it was mandatory to decolonize patients for $S$. aureus colonization (targeted or universal) prior to certain surgical 
medRxiv preprint doi: https://doi.org/10.1101/2020.07.08.20148791; this version posted July 10, 2020 . The copyright holder for this preprint (which was not certified by peer review) is the author/funder, who has granted medRxiv a license to display the preprint in perpetuity. It is made available under a CC-BY-ND 4.0 International license.

procedures, in particular in the presence of previously known MRSA colonization (12). If decolonization was performed after a patient was found to be colonized with $S$. aureus following preoperative $S$. aureus screening, this patient would have been included in the study cohort as S. aureus colonized, whereas the patient would have been decolonized before undergoing the surgical procedure. In such cases, the risk of patients developing a postoperative infection with S. aureus would be lower than if they would have not received any decolonization treatment $(27,28)$. If we would not correct for this, it could lead to erroneous conclusions. Therefore, we collect data on antibiotic usage, including data on preoperative decolonization treatment, and will be able to account for this in the analysis.

\section{Complexity of study procedures}

The study protocol dictated that patients from different surgical departments should be enrolled in the study and that these patients should be screened for $S$. aureus colonization prior to enrollment in the study cohort. To achieve this, the local study teams were required to have excellent communication with the participating surgical departments and laboratories. In addition, they had to have the resources to allow for the timely screening of patients. When setting-up this study in different sites across Europe, we encountered that most sites did not have a preoperative $S$. aureus screening policy for surgical patients already in place and that they struggled with implementing a preoperative screening policy. Also, the place and time when patients were seen prior to surgery by a healthcare professional differed quite significantly not only between sites, but also between surgical departments within one site. Because of this, local study teams had a difficult time approaching all eligible patients and arranging that samples were taken in a timely manner, which negatively impacted the full recruitment potential of the hospitals. We overcame these challenges by developing recruitment tools and by applying tailored solutions according to the individual needs of the participating sites. 
medRxiv preprint doi: https://doi.org/10.1101/2020.07.08.20148791; this version posted July 10, 2020 . The copyright holder for this preprint (which was not certified by peer review) is the author/funder, who has granted medRxiv a license to display the preprint in perpetuity.

It is made available under a CC-BY-ND 4.0 International license.

\section{Selection of sites}

To achieve the proposed sample size of the study cohort, we had to screen a great number of patients for S. aureus colonization. Because of budgetary and feasibility reasons, however, we could only select a limited number of sites for participation in the study. This implied that these sites should provide the necessary number of patients for the different surgical procedures for the study. We experienced that several countries did not have many hospitals with a large enough volume of patients to be able to recruit a certain number of subjects for the study. Because of this, the selection of suitable sites for the study took more time than expected. However, by taking the necessary time to select the best sites for the study, we ensured that the study could be executed within appropriate timelines and budget.

In conclusion, despite the challenges, this study will provide important information on the epidemiology of SSI and other infections caused by S. aureus in the current surgical population in Europe, thereby supporting the development of future clinical trials of effective interventions and public health interventions aimed at S. aureus SSI prevention.

\section{Future perspectives}

There are current efforts to develop novel therapies to combat the increasing problem of antimicrobial resistance. A promising new intervention is antibody-based pre-emptive therapy. A potential advantage of this novel intervention is that it may increase antibiotic effectiveness and may not lead to similar bacterial resistance as antibiotics (14). The current study aims not only to provide contemporary and important information on the incidence, patient-related and contextual factors of SSI and other 
medRxiv preprint doi: https://doi.org/10.1101/2020.07.08.20148791; this version posted July 10,2020 . The copyright holder for this preprint (which was not certified by peer review) is the author/funder, who has granted medRxiv a license to display the preprint in perpetuity. It is made available under a CC-BY-ND 4.0 International license.

infections caused by S. aureus in the surgical population in Europe, but also to provide data (i.e. sample size and target population) that will directly inform the design of future clinical trials. 
medRxiv preprint doi: https://doi.org/10.1101/2020.07.08.20148791; this version posted July 10,2020 . The copyright holder for this preprint (which was not certified by peer review) is the author/funder, who has granted medRxiv a license to display the preprint in perpetuity. It is made available under a CC-BY-ND 4.0 International license.

\section{CONCLUSIONS}

This prospective observational cohort study on S. aureus SSI and postoperative BSI in surgical patients will provide crucial information on the incidence and predictors for this event. Additionally, it will directly impact the design of future clinical trials aimed at $S$. aureus prevention.

\section{TRIAL STATUS}

This manuscript is based on the third version of the ASPIRE-SSI protocol, dated 30 January 2017. The first study cohort subject was enrolled in December 2016, and subject enrollment ended in January 2020.

\section{LIST OF ABBREVIATIONS}

ASA: American Society of Anesthesiologists; ASPIRE-SSI: Advanced Understanding of Staphylococcus aureus Infections in Europe - Surgical Site Infections; BSI: bloodstream infection; CDC: Centers for Disease Control and Prevention; COMBACTE: Combatting bacterial resistance in Europe; HAI: healthcareassociated infection; S. aureus: Staphylococcus aureus; SSI: surgical site infection; SDV: Source data verification. 
medRxiv preprint doi: https://doi.org/10.1101/2020.07.08.20148791; this version posted July 10, 2020 . The copyright holder for this preprint (which was not certified by peer review) is the author/funder, who has granted medRxiv a license to display the preprint in perpetuity.

It is made available under a CC-BY-ND 4.0 International license .

\section{DECLARATIONS}

\section{Ethics approval and consent to participate}

This study was conducted according to the principles of the Declaration of Helsinki (29), in accordance with the Medical Research Involving Human Subjects Act (WMO) and local guidelines in the participating countries. We received ethics approval of the study protocol, including informed consent procedures, from the Research Ethics Committee or Institutional Review Board of each participating site.

\section{Consent for publication}

Not applicable; this manuscript does not contain any individual person's data.

\section{Availability of data and material}

The datasets generated and analyzed during the study are not publicly available due to confidentiality reasons but are available from the corresponding author upon scientific review and approval of the request by the Study's Scientific Committee. A summary of the results will be published on clinicaltrials.gov and in peer-reviewed journals.

\section{Competing interests}

F.S. is currently an employee of Boehringer Pharmaceuticals and at the time of study design and conduct he was an employee of AstraZeneca. O.A. is an employee of AstraZeneca and holds stock in AstraZeneca. S.H. received fees for participation in a scientific advisory board of Sandoz.

\section{Funding}

This research project received support from the Innovative Medicines Initiative Joint Undertaking under grant agreement $n^{\circ} 115523$ resources of which were composed of financial contribution from the 
medRxiv preprint doi: https://doi.org/10.1101/2020.07.08.20148791; this version posted July 10,2020 . The copyright holder for this preprint (which was not certified by peer review) is the author/funder, who has granted medRxiv a license to display the preprint in perpetuity. It is made available under a CC-BY-ND 4.0 International license.

European Union Seventh Framework Programme (FP7/2007-2013) and EFPIA companies in kind contribution.

\section{Authors' contributions}

DPRT authored the original study protocol and this manuscript. DPRT, SW, LT, VT, SH, FS, OA and JAJW together created the study design. $\mathrm{MW}, \mathrm{DH}$ and $\mathrm{SW}$, with help of all other authors designed the Statistical Analysis Plan. All authors read and approved the study protocol and the final manuscript.

\section{Acknowledgements}

We would like to thank the following people for their contributions while writing this study protocol: Mohammed Abbas, Rubana Kalyani, Frank Coenjaerts, Christine Lammens, Edith Schasfoort, and Prof. Surbhi Malhotra-Kumar. 
medRxiv preprint doi: https://doi.org/10.1101/2020.07.08.20148791; this version posted July 10, 2020. The copyright holder for this preprint (which was not certified by peer review) is the author/funder, who has granted medRxiv a license to display the preprint in perpetuity. It is made available under a CC-BY-ND 4.0 International license .

\section{REFERENCES}

1. OECD/EU. Health at a Glance: Europe 2018: State of Health in the EU Cycle. Paris: OECD Publishing; 2018.

2. Sax H, Uçkay I, Balmelli C, Bernasconi E, Boubaker K, Mühlemann K, et al. Overall burden of healthcare-associated infections among surgical patients. Results of a national study. Ann Surg. 2011 Feb;253(2):365-70.

3. European Centre for Disease Prevention and Control (ECDC). Healthcare-associated infections: surgical site infections. Annual epidemiological report for 2017. Stockholm: ECDC; 2019.

4. Young PY, Khadaroo RG. Surgical site infections. Surg Clin North Am. 2014 Dec;94(6):1245-64.

5. Klevens RM, Edwards JR, Richards CL,Jr, Horan TC, Gaynes RP, Pollock DA, et al. Estimating health care-associated infections and deaths in U.S. hospitals, 2002. Public Health Rep. 2007 MarApr;122(2):160-6.

6. Cassini A, Plachouras D, Eckmanns T, Abu Sin M, Blank HP, Ducomble T, et al. Burden of Six Healthcare-Associated Infections on European Population Health: Estimating Incidence-Based DisabilityAdjusted Life Years through a Population Prevalence-Based Modelling Study. PLoS Med. 2016 Oct 18;13(10): e1002150.

7. Wertheim HF, Melles DC, Vos MC, van Leeuwen W, van Belkum A, Verbrugh HA, et al. The role of nasal carriage in Staphylococcus aureus infections. Lancet Infect Dis. 2005 Dec;5(12):751-62.

8. Kluytmans J, van Belkum A, Verbrugh H. Nasal carriage of Staphylococcus aureus: epidemiology, underlying mechanisms, and associated risks. Clin Microbiol Rev. 1997 Jul;10(3):505-20.

9. Abbas M, Aghayev E, Troillet N, Eisenring MC, Kuster SP, Widmer AF, et al. Temporal trends and epidemiology of Staphylococcus aureus surgical site infection in the Swiss surveillance network: a cohort study. J Hosp Infect. 2018 Feb;98(2):118-26.

10. Tong SY, Davis JS, Eichenberger E, Holland TL, Fowler VG,Jr. Staphylococcus aureus infections: epidemiology, pathophysiology, clinical manifestations, and management. Clin Microbiol Rev. 2015 Jul;28(3):603-61.

11. Ammerlaan HS, Harbarth S, Buiting AG, Crook DW, Fitzpatrick F, Hanberger $\mathrm{H}$, et al. Secular trends in nosocomial bloodstream infections: antibiotic-resistant bacteria increase the total burden of infection. Clin Infect Dis. 2013 Mar;56(6):798-805.

12. Lee AS, Pan A, Harbarth S, Patroni A, Chalfine A, Daikos GL, et al. Variable performance of models for predicting methicillin-resistant Staphylococcus aureus carriage in European surgical wards. BMC Infect Dis. 2015 Feb 27;15:105,015-0834-y. 
medRxiv preprint doi: https://doi.org/10.1101/2020.07.08.20148791; this version posted July 10, 2020. The copyright holder for this preprint (which was not certified by peer review) is the author/funder, who has granted medRxiv a license to display the preprint in perpetuity. It is made available under a CC-BY-ND 4.0 International license .

13. Paling FP, Olsen K, Ohneberg K, Wolkewitz M, Fowler VG,Jr, DiNubile MJ, et al. Risk prediction for Staphylococcus aureus surgical site infection following cardiothoracic surgery; A secondary analysis of the V710-P003 trial. PLoS One. 2018 Mar 21;13(3): e0193445.

14. Saylor C, Dadachova E, Casadevall A. Monoclonal antibody-based therapies for microbial diseases. Vaccine. 2009 Dec 30;27 Suppl 6(Suppl 6):G38-46.

15. Kostyanev T, Bonten MJ, O'Brien S, Steel H, Ross S, FranÃßois B, et al. The Innovative Medicines Initiative's New Drugs for Bad Bugs programme: European public-private partnerships for the development of new strategies to tackle antibiotic resistance. J Antimicrob Chemother. 2016 Feb;71(2):290-5.

16. Methodology: Standard country and area codes for statistical use (M49) [Internet]. New York, United States of America: United Nations Statistics Division; 2017 [cited 27-4-2020]. Available from: https://unstats.un.org/unsd/methodology/m49/.

17. Garner JS, Jarvis WR, Emori TG, Horan TC, Hughes JM. CDC definitions for nosocomial infections, 1988. Am J Infect Control. 1988 Jun;16(3):128-40.

18. Mangram AJ, Horan TC, Pearson ML, Silver LC, Jarvis WR. Guideline for Prevention of Surgical Site Infection, 1999. Centers for Disease Control and Prevention (CDC) Hospital Infection Control Practices Advisory Committee. Am J Infect Control. 1999 Apr;27(2):97,132; quiz 133-4; discussion 96.

19. Korol E, Johnston K, Waser N, Sifakis F, Jafri HS, Lo M, et al. A systematic review of risk factors associated with surgical site infections among surgical patients. PLoS One. 2013 Dec 18;8(12): e83743.

20. Kalmeijer MD, van Nieuwland-Bollen E, Bogaers-Hofman D, de Baere GA. Nasal carriage of Staphylococcus aureus is a major risk factor for surgical-site infections in orthopedic surgery. Infect Control Hosp Epidemiol. 2000 May;21(5):319-23.

21. Wolkewitz M, Cooper BS, Palomar-Martinez M, Alvarez-Lerma $F$, Olaechea-Astigarraga $P$, Barnett AG, et al. Multilevel competing risk models to evaluate the risk of nosocomial infection. Crit Care. 2014 Apr 8;18(2):R64.

22. Royston P, Moons KG, Altman DG, Vergouwe Y. Prognosis and prognostic research: Developing a prognostic model. BMJ. 2009 Mar 31;338:b604.

23. Sauerbrei W. The Use of Resampling Methods to Simplify Regression Models in Medical Statistics. Appl Statist. 1999;48(3):313-29.

24. Barnard J, Meng XL. Applications of multiple imputation in medical studies: from AIDS to NHANES. Stat Methods Med Res. 1999 Mar;8(1):17-36.

25. WHITE A. Increased Infection Rates in Heavy Nasal Carriers of Coagulase-Positive Staphylococci. Antimicrob Agents Chemother (Bethesda). 1963;161:667-70. 
medRxiv preprint doi: https://doi.org/10.1101/2020.07.08.20148791; this version posted July 10,2020 . The copyright holder for this preprint (which was not certified by peer review) is the author/funder, who has granted medRxiv a license to display the preprint in perpetuity. It is made available under a CC-BY-ND 4.0 International license .

26. Nouwen JL, Fieren MW, Snijders S, Verbrugh HA, van Belkum A. Persistent (not intermittent) nasal carriage of Staphylococcus aureus is the determinant of CPD-related infections. Kidney Int. 2005 Mar;67(3):1084-92.

27. van Rijen $M$, Bonten $M$, Wenzel R, Kluytmans J. Mupirocin ointment for preventing Staphylococcus aureus infections in nasal carriers. Cochrane Database Syst Rev. 2008 Oct 8;(4):CD006216. doi(4):CD006216.

28. Bode LG, Kluytmans JA, Wertheim HF, Bogaers D, Vandenbroucke-Grauls CM, Roosendaal R, et al. Preventing surgical-site infections in nasal carriers of Staphylococcus aureus. N Engl J Med. 2010 Jan 7;362(1):9-17.

29. World Medical Association. World Medical Association Declaration of Helsinki: ethical principles for medical research involving human subjects. JAMA. 2013 Nov 27;310(20):2191-4. 